\title{
Systematization and comparative scheme analysis of mechanisms of planetary rotary hydraulic machines
}

\author{
Gleb Volkov ${ }^{1, *}$, and Vladimir Smirnov ${ }^{2}$ \\ ${ }^{1}$ Kurgan State University, the city of Kurgan 640020 Building 4, 63 Sovetskaya str., Russia
}

\begin{abstract}
The systematization of planetary rotary hydraulic machines (PRHM) with floating rollers is presented in the article. This systematization is carried out according to such structural features as: the number of waves that have central tooth gears with internal and external teeth, the character of the leading link motion; selection of a supporting (fixed) link; selection of the link containing the channels. The systematization allows us to list all essentially different schemes of PRHM and conduct their comparative analysis. The comparison is based on such technical parameters as: symmetry of schemes; absence of dead spots; PRHM performance, pulsation of instantaneous performance; channel cross-sectional area. The comparison showed that based on a set of indicators, the schemes with the numbers of central wheel waves $2 \times 4 ; 4 \times 6$; $6 \times 8$ are preferred, in which the rotor performs a purely rotary motion.
\end{abstract}

Today virtually all types of industry cannot do without volumetric hydraulic machines. Improving the technical characteristics of such machines is highly demanded and relevant.

One of the perspective types of volumetric hydraulic machines is planetary rotary hydraulic machines (PRHM) - Figure 1. All such hydraulic machines contain Link 1 with external teeth, Link 2 with internal teeth and intervening Floating rollers 3. During the motion of the Driving link 1 (or 2) the volume of the cavity located between Rollers 3 varies, and Rollers 3, rolling between Links 1 and 2, open and close the respective channels.

Although, according to their mass-produced indicators, PRHMs exceed [1] other volumetric hydraulic machines, until now they have not been widely used. This is due to the lack of economically feasible technologies for manufacturing non-circular tooth gears, as well as the lack of appropriate calculation techniques. The first task to be solved is creation of a consistent scientific classification and selection of the most promising schemes of PRHM.

The main distinguishing feature of such machines is combination of numbers of link waves $(\mathrm{M})$ with external teeth and the number of link waves $(\mathrm{N})$ link with internal teeth $[2$, 3]. However, there are many possible combinations of $\mathrm{M} \times \mathrm{N}$ numbers of waves. We propose to group them, distinguishing only: $1, \mathrm{i}$ and $\mathrm{j}$, where $1<\mathrm{i}<\mathrm{j}$. In this case, there are only five possible combinations:

\footnotetext{
*Corresponding author: vlkv48@,mail.ru
} 
$1 \times 1 ; \quad 1 \times \mathrm{i} ; \quad \mathrm{i} \times 1 ; \quad \mathrm{i} \times \mathrm{i} ; \quad \mathrm{i} \times \mathrm{j}$.
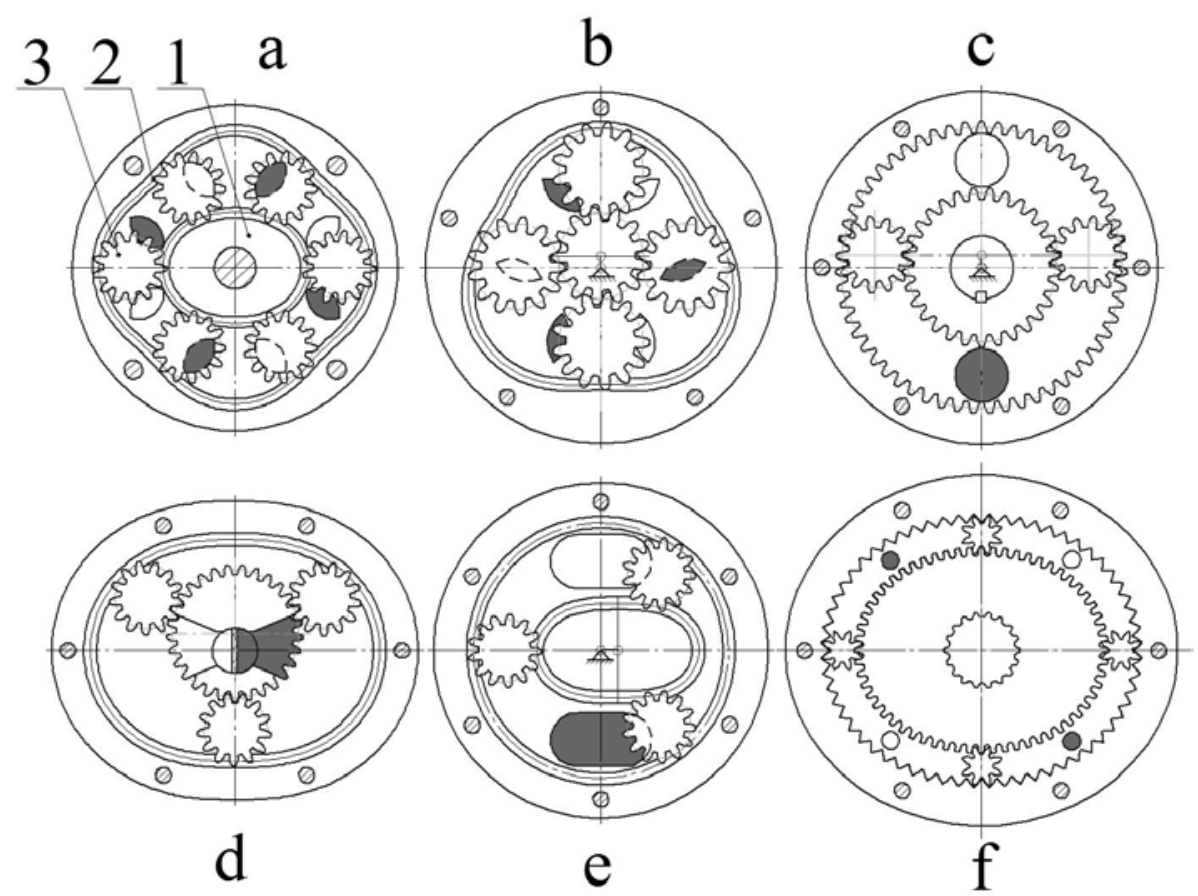

$\mathrm{a}\left(2 \times 4_{f}^{k}-R\right) ; \mathrm{b}\left(1 \times 3_{\mathrm{f}}^{\mathrm{k}}-\mathrm{R}\right) ; \mathrm{c}\left(1 \times 1_{\mathrm{f}}^{\mathrm{k}}-\mathrm{P}\right) ; \mathrm{d}\left(1^{\mathrm{k}} \times 2_{\mathrm{f}}-\mathrm{R}\right) ; \mathrm{e}\left(2 \times 1_{\mathrm{f}}^{\mathrm{k}}-\mathrm{P}\right) ; \mathrm{f}\left(2 \times 2_{\mathrm{f}}^{\mathrm{k}}-\mathrm{R}\right)$

Fig. 1. Schemes of PRHM

In addition, we introduce another important feature - the character of the leading link motion. In this case, we single out the cases of:

- purely rotational motion of the driving link - R;

- planetary movement of the leading link - P;

The schemes a, b, d, f refer to the first case (Fig. 1). The schemes c and e refer to the second case. It is important that in the second case one of the links is necessarily circular, i.e. has a number of waves $\mathrm{M}$ or $\mathrm{N}=1$. Round links can rotate "within themselves", without changing the position of other links touching them.

As a result, we get only 10 non-recurring formal combinations of $\mathrm{M} \times \mathrm{N}$, of which only 7 groups of mechanisms are of practical importance: $1 \times 1-\mathrm{R} ; 1 \times 1-\mathrm{P} ; 1 \times \mathrm{i}-\mathrm{R} ; 1 \times \mathrm{i}-\mathrm{P} \quad \mathrm{i} \times 1-\mathrm{P}$; $\mathrm{i} \times \mathrm{i}-\mathrm{R} ; \mathrm{i} \times \mathrm{j}-\mathrm{R}$, which are summarized in Table 1 .

Table 1. Groups of PRHM

\begin{tabular}{|c|c|c|c|c|}
\hline & \multicolumn{5}{|c|}{ Number of link waves with externl teeth, (M) } \\
\hline \multirow{2}{*}{$\begin{array}{c}\text { Number of link } \\
\text { waves with internal } \\
\text { teeth, (N) }\end{array}$} & & \multicolumn{2}{|c|}{1} & $\mathrm{i}$ \\
\cline { 2 - 5 } & $\mathrm{i}$ & $\mathrm{P}$ & $\mathrm{R}$ & $\mathrm{P}$ \\
\cline { 2 - 4 } & $\mathrm{j}$ & $\mathrm{P}$ & $\mathrm{R}$ & $\mathrm{R}$ \\
\hline \multicolumn{5}{|c|}{$1<\mathrm{i}<\mathrm{j}$} \\
\hline
\end{tabular}

The mechanism belonging to the specific cell of Table 1 will characterize its main distinguishing features. 
The significant structural features of the working mechanism of the hydraulic machine are also selection of the stopped link - index " $\mathrm{f}$ " and the link in which the channels are made - index "k".

The proposed systematization of PRHM made it possible to carry out an orderly enumeration of their basic schemes. Table 2 presents the results of a comparative evaluation of these schemes based on the technical indicators, such as: scheme symmetry; absence of dead spots; PRHM performance, pulsation of instantaneous performance; channel cross-sectional area.

The scheme symmetry ensures the forces application symmetry and unloading of the shaft supports. The absence of such symmetry makes it impossible to use PRHM at large pressures of the medium.

Dead spots are only present in the PRHM of the $1 \times 1-\mathrm{P}$ group. Overcoming these dead spots requires a significant complication of the PRHM mechanism.

For comparative evaluation of PRGM productivity, the ratio of the end section volume area displaced per rotor revolution, referred to the inner initial curve of the PRGM central wheel with internal teeth (epicycles) was used. Determination of the capacity factor was carried out for specific schemes using the graphical method [4].

The channel cross-section factor was also defined as the ratio of the cross-sectional area of the input (or output) channels to the area located inside the initial curve of the PRGM central wheel with internal teeth [5]. Two cases were considered - when the channels were made in the end walls of an epicycle or in a central gear. The data on the structures where the channels were made in the cylindrical working surfaces of the central gears were not included in the table.

Flow pulsation, i.e. the instantaneous PRGM productivity, was determined on basis of the harmonic nature of the variation in the flow rate of each working cavity. Its value depends on the number of cavities consecutively included in the cycle. A pulsation value of $\pm 50 \%$ means that the flow rate of the medium varies from zero to maximum, i.e. occurs in separate portions.

Table 2 is to be expanded in the future through the introduction of other technical indicators, however, certain conclusions can be made at this stage of the study. For use on the limiting pressure of the medium, only PRGM of $i \times j-R$ and $i \times i-R$ groups are suitable. At the same time, the $\mathrm{i} \times \mathrm{j}-\mathrm{R}$ group has advantages in terms of channel sizes and less pulsation of the medium flow. We should note that such conclusions are not unexpected, since the only known PRGM, produced serially [6] $-4{ }^{k} \times 6_{f}^{k}-R$, refers specifically to this group.

\section{Conclusion}

The proposed systematization allows to identify all essentially different schemes of PRGM and compare them among themselves according to the most important criteria and choose the best. According to the research state, the ixj-R group has a certain advantage at the moment.

This research was supported by the Russian Foundation for Basic Research and the Government of the Kurgan Region within the framework of the scientific project No. 17-48-450262. 
Table 2. The main schemes of PRGM

\begin{tabular}{|c|c|c|c|c|c|c|c|}
\hline \multirow{3}{*}{$\stackrel{0}{\tilde{\Xi}}$} & \multirow{3}{*}{ Schemes } & \multirow{3}{*}{$\begin{array}{c}\text { Sourc } \\
\mathrm{e}\end{array}$} & \multicolumn{5}{|c|}{ Performance characteristics } \\
\hline & & & \multirow{2}{*}{$\begin{array}{c}\text { Symmetr } \\
\text { ical } \\
\text { / without } \\
\text { dead } \\
\text { spots }\end{array}$} & \multirow{2}{*}{$\begin{array}{l}\text { Capacity } \\
\text { factor }\end{array}$} & \multicolumn{2}{|c|}{$\begin{array}{c}\text { Channel section } \\
\text { factor }\end{array}$} & \multirow{2}{*}{$\begin{array}{c}\text { Flow } \\
\text { pulsation, } \\
\pm \%\end{array}$} \\
\hline & & & & & $\begin{array}{c}\text { in } \\
\text { epicycl } \\
\text { e }\end{array}$ & $\begin{array}{c}\text { in } \\
\text { central } \\
\text { gear }\end{array}$ & \\
\hline \multirow{5}{*}{$\frac{x}{1}$} & $2 \times 4_{f}^{k}-R$ & {$[7]$} & $+1+$ & 0.32 & 0.0591 & - & $\pm 17 \%$ \\
\hline & $3 \times 4_{f}^{k}-R$ & [8] & $-1+$ & 0.49 & 0.0150 & - & $\pm 7 \%$ \\
\hline & $3_{\mathrm{f}}^{\mathrm{k}} \times 4-\mathrm{R}$ & [9] & $-1+$ & 0.49 & - & 0.0556 & $\pm 7 \%$ \\
\hline & $4^{\mathrm{k}} \times 6_{\mathrm{f}}^{\mathrm{k}}-\mathrm{R}$ & \multirow{2}{*}[10]{} & \multirow{2}{*}{$+1+$} & 0.49 & 0.0605 & 0.1165 & $\pm 7 \%$ \\
\hline & $6^{\mathrm{k}} \times 8_{\mathrm{f}}^{\mathrm{k}}-\mathrm{R}$ & & & 0.51 & 0.0539 & 0.0856 & $\pm 4 \%$ \\
\hline \multirow{3}{*}{$\frac{x}{1}$} & $1^{\mathrm{k}} \times 2_{\mathrm{f}}-\mathrm{R}$ & [11] & \multirow{3}{*}{$-1+$} & 0.3 & - & 0.1355 & \multirow{2}{*}{ $\pm 17 \%$} \\
\hline & $1 \times 2 \mathrm{f}-\mathrm{R}$ & [5] & & 0.3 & 0 & - & \\
\hline & $1 \times 3_{\mathrm{f}}^{\mathrm{k}}-\mathrm{R}$ & [12] & & 0.16 & 0.0420 & - & $\pm 4 \%$ \\
\hline$\frac{a}{x}$ & $1 \times 2 \underset{f}{k}-P$ & [13] & $-1+$ & 0.3 & - & $\leq 0.1$ & $\pm 17 \%$ \\
\hline$\frac{1}{x}$ & $2 \times 1_{f}^{k}-P$ & [3] & $-1+$ & 0.33 & 0.11 & - & $\pm 17 \%$ \\
\hline$\frac{i}{x}$ & $1 \times 1_{f}^{k}-P$ & $\begin{array}{l}{[14]} \\
{[15]} \\
{[16]}\end{array}$ & $-1-$ & $\leq 0.47$ & $\leq 0.1$ & - & $\pm 50 \%$ \\
\hline$\frac{\underline{1}}{\underline{x}}$ & $1 \times 1_{f}^{k}-R$ & {$[17]$} & $-1+$ & 0.20 & 0.0049 & - & $\pm 50 \%$ \\
\hline \multirow{2}{*}{$\frac{x}{1}$} & $2 \times 2{ }_{f}^{k}-R$ & \multirow{2}{*}[18]{} & \multirow{2}{*}{$+1+$} & 0.37 & 0.0098 & - & $\pm 50 \%$ \\
\hline & $3 \times 3_{f}^{k}-R$ & & & 0.50 & 0.0147 & - & $\pm 50 \%$ \\
\hline
\end{tabular}




\section{References}

1. Z.L. Finkelshtein, A.P. Palyukh, High-torque planetary hydromotors with floating rollers - creating small-scale mining equipment, Collection of scientific works of Donbass State Technical University, Volume 39, pp. 24-30 (2013).

2. An I-Kan, Synthesis, geometric and strength calculations of planetary mechanisms with non-circular gear wheels of rotary hydraulic machines: the author's abstract. ... Dr. of tech. sciences. Tomsk: 2001. - 35 P.

3. Patent WO0166948 A positive-displacement machine of gear type / Zhang Quan. Published 13.09.2001.

4. G.Yu. Volkov, V.V. Smirnov, M.V. Gorbunov, Calculation of relative productivity of planetary rotary hydraulic machines, Bulletin of Kurgan State University. - Series "Technical Sciences", Volume 2 (45), pp. 28-31 (2017).

5. V.V. Smirnov, Calculation and comparative estimation of channel cross-sections in the end walls of planetary rotary hydraulic machines, Handbook. Engineering Journal, Vol. 6 (accepted for printing).

6. Official website of HYDROMECH plant. Access mode www.hydromech-pac.pl.

7. Patent RU2137943 Rotary hydraulic machine / An I-Kan. Publ. 20.09.1999.

8. Patent SU1403993 Planetary-cam motor/Bogdan Sinyavsky, Jezhy Potulski, Daryush Sinyavsky. Publ. 15/06/1988. Bul. No. 22.

9. Patent SU484710 МПК F04C 1/08. Volumetric rotary engine / Bogdan Sinyavsky. Publ. 09/15/1975. Bul. No. 34.

10. Patent US6230823 МПК Е21B 4/02. Downhole motor / Dariusz Sieniawski. Publ. 15.05.2001

11. Patent SU861734 МПК F04C 2/06. Gear hydraulic machine of internal gearing / Kostikov N.I., Nazarov I.I., Doronin N.F. Publ. 7/09/1981. Bul. No. 33.

12. Patent DE288340 MПК F01C 1/10; MПК F01C 1/113; MПК F04C 2/063; MПК F04C 2/10; МПК F04C 2/12. Mashine mit einer Mehrzahl von Gehauseinnern angeordneten, zwischen der Gehausewand und mittleren, relative zum Gehause drehbaren Kolben eingeschalteten Kolbenkorpern / BRISCOE AND DOCK ENGINEERING COMPANY in WILMINGTON, Delaware, V. St. A. Publ. 11.09.1913.

13. G.Yu. Volkov, V.V. Smirnov, Kinematic and functional features of volumetric hydraulic machines with planetary motion of the rotor and satellites, Bulletin of the Kurgan State Agricultural Academy named after T.S. Maltsev, Vol. 3 (23), pp. 61-65 (2017).

14. Patent SU699229 МПК F04C 1/06. Gear Hydraulic Machine / Kostikov N.I., Nazarov I.I., Mospan B.F. Publ. 25.11.1979. Bul. No. 43.

15. Patent GB1158638 МПК F01C 1/04, МПК G01F 1/00. Rotary Positive-Displacement Fluid-Driven Motors, Fluid Pumps, Meters or the Like / John Arthur Halliwell. Publ. 16.07.1969.

16. Patent RU2445512 МПК F04C 2/08 МПК F04C 2/14. The rotary hydro machine / Volkov G.Yu., Smirnov V.V. Publ. 10.11.2011. Bul. No. 31.

17. Patent RU2513057 МПК F04C 2/08, МПК F04C 2/14. The rotary hydro machine / Volkov G.Yu., Publ. 20.04.2014. Bul. No. 11.

18. Patent RU144306 МПК F04C 2/08, МПК F04C 2/14. The rotary hydro machine / Volkov G.Yu., Kurasov D.A. Publ. 20.08.2014. Bul. No. 23. 